\title{
Lower global warming potential and higher yield of wet direct-seeded rice in Central China
}

\author{
Ye Tao $^{1} \cdot$ Qian Chen ${ }^{1} \cdot$ Shaobing Peng ${ }^{1} \cdot$ Weiqin Wang ${ }^{1} \cdot$ Lixiao Nie $^{1,2}$
}

Accepted: 22 March 2016/Published online: 7 April 2016

(C) INRA and Springer-Verlag France 2016

\begin{abstract}
Direct-seeded rice is a promising option because it saves water and labor, and it increases productivity. Nonetheless, few studies have evaluated the transition from traditionally transplanted rice to direct-seeded rice. Here we compared yield, water productivity, and greenhouse gas emissions of dry direct-seeded rice, wet direct-seeded rice, and transplanted rice in Central China in 2014 and 2015. We grew four rice cultivars: Huanghuazhan, LvdaoQ7, Yangliangyou6, and Yliangyoul. We measured grain yield, yield components, water consumption, water productivity, and greenhouse gas emissions. Our results show that the grain yield of wet direct-seeded rice was $10.8 \%$ higher than that of transplanted rice, when averaged across cultivars and both years. Grain yield of dry direct-seeded rice and transplanted rice was similar. Water productivity of dry direct-seeded rice was $11.6 \%$ higher than that of transplanted rice. Water productivity of wet direct-seeded rice was $13.4 \%$ higher than that of transplanted rice. Global warming potential was $76.2 \%$ lower for dry direct-seeded rice and $60.4 \%$ lower for wet direct-seeded rice than for transplanted rice. Wet direct-seeded rice was found to be more susceptible to lodging than dry direct-seeded rice and transplanted rice. Overall, wet direct-seeded rice is the best system for Central China due to higher grain yield and water
\end{abstract}

Lixiao Nie

nielixiao@mail.hzau.edu.cn

1 National Key Laboratory of Crop Genetic Improvement, MOA Key Laboratory of Crop Ecophysiology and Farming System in the

Middle Reaches of the Yangtze River, College of Plant Science and Technology, Huazhong Agricultural University,

Wuhan, Hubei 430070, China

2 Hubei Collaborative Innovation Center for Grain Industry, Yangtze University, Jingzhou, Hubei 434023, China productivity and lower global warming potential. Dry directseeded rice may also be suitable for some regions where water is scarce for soil puddling during land preparation.

Keywords Dry direct-seeded rice $\cdot$ Wet direct-seeded rice . Transplanted rice · Grain yield · Water productivity · Greenhouse gas emission

\section{Introduction}

Globally, water is becoming an increasingly scarce resource (Kumar and Ladha 2011). Transplanted rice, which refers to the process of transplanting rice seedlings from nursery beds to puddled soil, is the major rice crop establishment method in China (Peng et al. 2009). However, transplanted rice is always considered to waste water, as large quantities of water are consumed during the land preparation and farming processes (Bouman 2009). Compared with other cereal crops such as wheat and maize, transplanted-flooded rice consumes two or three times more water (Barker et al. 1998; Carriger and Vallée 2007). Large amounts of water are required for puddling, most of which is wasted through surface evaporation and percolation (Farooq et al. 2011). Furthermore, the water use efficiency of transplanted rice is low. It has been reported that with the consumption of $1 \mathrm{~m}^{3}$ water, less than $1 \mathrm{~kg}$ grains were produced (Bouman 2009). Another factor that is a severe obstacle for rice production in China is that the high demand for labor during transplanting severely conflicts with the labor shortage in the Chinese agricultural system. Thus, the traditionally transplanted rice, which has a high labor demand, is no longer suitable for sustainable development in China, suggesting that mechanization is the only way to reasonably and effectively solve these problems. However, the mechanization level for transplanted rice is still low. Although mechanization during 
rice harvesting has been widely adapted by rice farmers, sowing mechanization is still lagging. It has been reported that mechanization levels for rice during land preparation and harvesting reached 91 and $70 \%$, respectively, by the end of 2011, but the mechanization level during rice establishment (including seed sowing and transplanting) could only reach $26 \%$ (Chen et al. 2015). This is mainly due to the complexity of transplanting. For example, paddy fields are small and scattered, which is not suitable for machinery operation. Poor seedling quality and a high rate of vacancy on hills also restrict the mechanical transplantation of rice. In contrast, direct-seeded rice, which refers to the process of directly sowing the seeds in the field instead of transplanting rice seedlings, has been proposed to reduce water requirements and save energy, and works well with mechanization for rice planting. Mechanical direct seeding of rice has simpler steps compared with mechanically transplanting rice. With the development of herbicides, there is a rising trend of using mechanical direct seeding for rice in China (Wang et al. 2006). The following direct-seeding methods have been suggested for rice in China: (1) dry direct-seeded rice, in which dry rice seeds are drilled or broadcasted on non-puddled soil after dry tillage, zero tillage, or on a raised bed, and (2) wet direct-seeded rice, in which dry seeds or sprouted rice seeds are broadcast or sown in lines on wet and puddled soil. Another principal method of direct-seeded rice is water seeding, in which sprouted rice seeds are broadcast in soil withstanding water (Kumar and Ladha 2011). Previous studies have compared the variances between different types of direct-seeded rice and traditional transplanted rice for yield, water use efficiency, and establishment methods. Generally, the yield performance of dry direct-seeded rice and wet direct-seeded rice was close to the yield of traditional transplanted rice (Mitchell et al. 2004; Rickman et al. 2001). Meanwhile, direct-seeded rice required lower irrigation water due to fewer continuous flooded days in the main field and less water use during land preparation compared with traditional transplanted rice. Zhao et al. (2007) documented higher grain yields and lower water use for dry direct-seeded rice compared with transplanted rice.

Agriculture is considered a major anthropogenic source of $\mathrm{CH}_{4}$ and $\mathrm{N}_{2} \mathrm{O}$, accounting for 50 and $60 \%$ of total $\mathrm{CH}_{4}$ and $\mathrm{N}_{2} \mathrm{O}$ emissions, respectively, in 2005 (Smith et al. 2007). Conventionally transplanted rice contributes a lot to the emission of greenhouse gases (GHGs), particularly methane $\left(\mathrm{CH}_{4}\right)$ and nitrous oxide $\left(\mathrm{N}_{2} \mathrm{O}\right)$. Rice paddies have been identified as a major source of $\mathrm{CH}_{4}$, amounting to $11 \%$ of global total anthropogenic $\mathrm{CH}_{4}$ emissions (Smith et al. 2007). Furthermore, emission of GHGs from rice fields is highly sensitive to rice management practices; there are differences in the amount of greenhouse gas emissions from different rice establishment methods. Wassmann et al. (2004) reported that total $\mathrm{CH}_{4}$ emissions were reduced in direct-seeded rice fields compared with transplanted rice. Previous research has also indicated that direct-seeded rice would simultaneously decrease $\mathrm{CH}_{4}$ but enhance $\mathrm{N}_{2} \mathrm{O}$ emissions (Shang et al. 2011). However, further studies are needed to update our knowledge on $\mathrm{CH}_{4}$ and $\mathrm{N}_{2} \mathrm{O}$ emissions from different direct-seeded rice systems.

With the advantages of water and labor saving, increasing system productivity, and matching the development of new types of mechanization equipment, direct-seeded rice has been proposed as a promising option for rice production. To date, few studies have been conducted to investigate the crop performance of dry direct-seeded and wet direct-seeded rice under well-watered soil conditions. Central China is one of the largest rice planting regions in China, where planting areas for direct-seeded rice is increasing rapidly. To evaluate the potential of shifting from transplanted rice to dry direct-seeded rice and wet direct-seeded rice in terms of grain yield performance, water use efficiency, and greenhouse gas emissions, two-year field experiments were conducted for the three establishment methods (Fig. 1).

\section{Material and methods}

\subsection{Study site}

The field experiments were conducted at the Zhougan Village $\left(29^{\circ} 51^{\prime} \mathrm{N}, 115^{\circ} 33^{\prime} \mathrm{E}\right)$, Dajin Town, Wuxue County, Hubei Province, China, in 2014 and 2015. In each year, soil samples were collected once from the upper $20 \mathrm{~cm}$ of the surface before the experiments were started. The $\mathrm{pH}$, organic matter, total nitrogen, available phosphorus, and extractable potassium were 5.07, $21.0 \mathrm{~g} \mathrm{~kg}^{-1}, 0.17 \%, 10.56 \mathrm{mg} \mathrm{kg}^{-1}$, and $91.8 \mathrm{mg} \mathrm{kg}^{-1}$, respectively.

\subsection{Experimental design}

In this study, the following three establishment methods were adopted: (1) dry direct-seeding rice, (2) wet direct-seeding rice, and (3) transplanting rice. The following four indica rice cultivars were used: (1) Huanghuazhan (inbred), (2) LvdaoQ7 (inbred), (3) Yangliangyou6 (hybrid), and (4) Yliangyou1 (hybrid), which are widely grown by rice farmers in Central China. The treatments were randomly arranged using a splitplot design; the establishment methods were assigned in the main plots, and cultivars were assigned in the sub-plot $(3.9 \mathrm{~m} \times 5.6 \mathrm{~m})$ with four replicates. Soil in the dry directseeded rice plots was dry-ploughed and harrowed without water puddling, and the dry seeds were sown manually in rows with a row space of $25 \mathrm{~cm}$ at a sowing rate of $60 \mathrm{~kg} \mathrm{ha}^{-1}$. Different from dry direct-seeded rice, both wet direct-seeded rice and transplanted rice plots were ploughed and puddled before seed sowing or transplanting. The sowing density and rate in wet direct-seeded rice were the same as in 

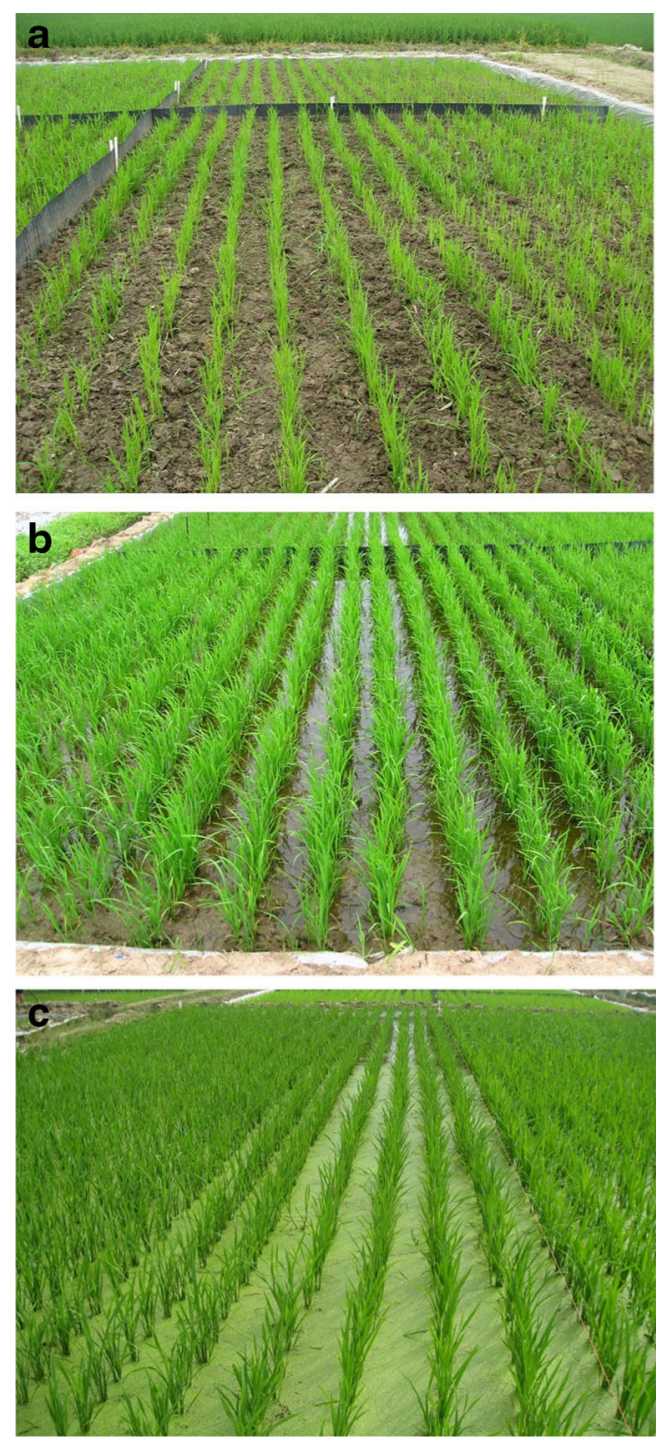

Fig. 1 Seedling growth of a dry direct-seeded rice $(D D S R)$, b wet directseeded rice $(W D S R)$, and $\mathbf{c}$ transplanted-flooded rice $(T R)$ during the early vegetative stage

dry direct-seeded rice. In dry direct-seeded rice, the dry seeds were sown on May 3, 2014, and April 15, 2015. The sowing dates for wet direct-seeded rice were May 5, 2014, and April 15,2015 . For transplanted rice, the seeds were sown in nurseries on May 1,2014, and April 15, 2015. Seedlings that were 27 and 31 days old were transplanted into the paddy soil with a hill spacing of $25 \times 13.3 \mathrm{~cm}$ with three seedlings per hill on May 27, 2014, and May 16, 2015, respectively. The dry direct-seeded rice plots were not irrigated (kept rainfed) until May 21, 2014, and May 8, 2015, respectively. From then on, $5-10 \mathrm{~cm}$ of standing water was kept in the plots until 1 week before harvest. The soil in the wet direct-seeded rice plots was kept saturated before May 21, 2014, and May 8, 2015, and then, $5-10 \mathrm{~cm}$ of water was maintained until 1 week before harvest. The amount of irrigation water was recorded by a water meter that was connected to the pump.
A fertilizer dose of 150:40:100 kg N:P:K ha ${ }^{-1}$ was applied equally to all of the treatments. All of the $\mathrm{P}$, one third of the $\mathrm{N}$, and half of the $\mathrm{K}$ were applied as a basal starter dose, while the residual $\mathrm{N}$ was equally split at the middle tillering stage and the panicle initiation stage, and the other $50 \%$ of the potassium was top-dressed during panicle initiation. Weeds, diseases, and insects were intensively controlled during the entire growing season in both years.

\subsection{Data collection}

\subsubsection{Plant growth, grain yield, and yield components}

At the physiological maturity stage, $0.5 \mathrm{~m}^{2}$ of plants (two adjacent rows and $1 \mathrm{~m}$ in length for dry direct-seeded rice and wet direct-seeded rice and 15 hills for transplanted rice) were collected to determine the yield components, aboveground biomass, and harvest index. The grain yield was determined from a sampling area of $5 \mathrm{~m}^{2}$ in the center of each plot, and the yields were calculated with a grain moisture content of $0.14 \mathrm{~g} \mathrm{H}_{2} \mathrm{O} \mathrm{g}^{-1}$.

\subsubsection{Greenhouse gas samples}

For each establishment method, two cultivars, Huanghuazhan and Yangliangyou6, were chosen for the determination of greenhouse gas emissions. $\mathrm{CH}_{4}$ and $\mathrm{N}_{2} \mathrm{O}$ flux were determined using the closed-chamber technique (Pathak et al. 2002) with two different-sized chambers $(0.5 \mathrm{~m}$ length $\times 0.3 \mathrm{~m}$ width $\times 0.65 \mathrm{~m}$ height and $0.5 \mathrm{~m}$ length $\times 0.3 \mathrm{~m}$ width $\times 1.3 \mathrm{~m}$ height). The chamber consisted of acrylics and six flux collars. All of the chambers were made from the same materials with the same lengths and widths. The base of each chamber was permanently installed in the fields during rice growing season. The top edge of the collar base exhibits a groove $(5 \mathrm{~cm}$ in depth) that can be filled with water to seal the rim of the chamber during gas sampling. An electric fan was set to ensure complete gas mixing, and the chambers were covered by sunshade cloth to minimize air temperature changes inside the chamber during the sampling. Gas sampling began 1 day after transplanting. Gas sample intervals were 14 days in 2014 and 7 days in 2015. The gases were sampled from inside the chambers using $100-\mathrm{mL}$ plastic syringes fitted with three-way stopcocks at 0,10 , and $20 \mathrm{~min}$ after chamber closure, and followed by infusion into an empty aluminum foil gas collecting bag. The sampling time was between 9:00 a.m. and 11:00 a.m. on each sampling day. The gas samples were transported to the laboratory for analysis by gas chromatography within a few hours. The concentrations of $\mathrm{CH}_{4}$ and $\mathrm{N}_{2} \mathrm{O}$ were analyzed with a gas chromatograph meter (Shimadzu GC-14B; Kyoto, Japan) equipped with an electron capture detector for $\mathrm{N}_{2} \mathrm{O}$ analysis and a flame ionization detector for $\mathrm{CH}_{4}$ analysis. $\mathrm{N}_{2}$ (flow rate of 
$330 \mathrm{ml} \mathrm{min}^{-1}$ ) and $\mathrm{H}_{2}$ (flow rate of $30 \mathrm{ml} \mathrm{min}^{-1}$ ) were used as the carrier and fuel gas, respectively. The temperatures of the column, injector, and detector were set at 55,100 , and $200^{\circ} \mathrm{C}$, respectively. Fluxes were determined from the slope of the mixing ratio change in three samples. Global warming potential was introduced to estimate the potential future impact of the emissions of different gases on the climate system in a relative sense (Lashof and Ahuja 1990). $\mathrm{CO}_{2}$ is generally taken as the reference gas. Global warming potential $\left(\mathrm{kg} \mathrm{CO}_{2}\right.$ equivalents $\mathrm{ha}^{-1}$ ) was calculated using the following equation: Global warming potential $(\mathrm{GWP})=\mathrm{CH}_{4} \times 25+\mathrm{N}_{2} \mathrm{O} \times 298$ and is based on a 100-year time frame. The total $\mathrm{CH}_{4}$ emission, total $\mathrm{N}_{2} \mathrm{O}$ emission, and global warming potential were calculated by the average of two cultivars.

\subsection{Weather data}

Meteorological data, except rainfall, were collected from a weather station (CR800; Campbell, USA) near the experimental field which included daily average temperature and solar radiation. Rainfall was recorded by a rain gauge located near the experiment site.

\subsection{Data analysis}

The data were analyzed with Statistix 8.0, and the mean of the treatments were compared with the least significant difference test (LSD). Graphical representation of the data was made using Sigmaplot 10.0.

\section{Results and discussion}

\subsection{Grain yield and yield components}

The grain yield was the highest in wet direct-seeded rice, while the grain yields in dry direct-seeded rice were comparable to those in transplanted rice (Table 2). On average, wet direct-seeded rice produced 7.8 and $13.7 \%$ more grain yield than transplanted rice in 2014 and 2015, respectively. The number of spikelets per square meter was highest in wet direct-seeded rice due to the highest panicle number per square meter among the three establishment methods (Table 2). The grain filling percentage and grain weight in wet direct-seeded rice were close to those in dry directseeded rice and transplanted rice. Thus, the grain yield was highest in wet direct-seeded rice among the three establishment methods. In 2014, the grain yields of YLiangyou1 were not significantly different among the three establishment methods because of the serious lodging that occurred in wet direct-seeded rice. In 2014, the hybrid rice varieties YLiangyou1 and Yanglaingyou6 had a higher number of panicles per square meter in dry direct-seeded rice and more spikelets per panicle in transplanted rice, resulting in no significant differences in the number of spikelets per square meter between these two crop systems. LvdaoQ7 displayed a higher grain weight and grain filling in dry direct-seeded rice, though there were more panicles and spikelets per square meter in transplanted rice, which led to similar yields. In 2015, the performances of grain yield and yield components under different establishment methods showed the similar trends to that in 2014.

\subsection{Irrigation and water productivity}

The amount of precipitation was greater in 2014 during the rice growing season than in 2015 (Table 1). In transplanted rice, water consumption for puddling, and irrigation accounted for approximately 34 and $55 \%$ of the total water input in 2014 and 2015, respectively (Table 1). When averaged across the different rice establishment methods and cultivars, the total water input (including rainfall and irrigation) for dry direct-seeded rice was reduced by 7.1 and $4.5 \%$ compared with that for wet direct-seeded rice and transplanted rice in 2014, respectively, and reduced by 5.4 and $11.0 \%$ in 2015, respectively. The irrigation water consumption in dry directseeded rice was reduced by 24.7 and $13.3 \%$ compared with that in wet direct-seeded rice and transplanted rice, respectively, when averaged across 2 years (Table 1). Number of irrigations in dry direct-seeded rice was also less than in wet directseeded rice and transplanted rice (Table 1). In the present study, water productivities in the two direct-seeded rice systems were significantly higher than that in the transplanted rice system (Fig. 2). On average and between the cultivars, water productivity in dry direct-seeded rice and wet directseeded rice was 7.5 and $6.2 \%$ higher than transplanted rice in 2014 and 15.6 and $20.6 \%$ higher in 2015, respectively. In dry direct-seeded rice, comparable grain yields to transplanted rice were achieved with much less water input. Meanwhile, wet direct-seeded rice achieved significantly higher grain yields than transplanted rice with similar amounts of water consumption, indicating that water productivity was significantly higher in the two direct-seeded rice systems compared with transplanted rice.

\section{3 $\mathrm{CH}_{4}$ and $\mathrm{N}_{2} \mathrm{O}$ emissions and global warming potential}

Seasonal total $\mathrm{CH}_{4}$ emissions from transplanted rice were significantly higher than from dry direct-seeded rice or wet direct-seeded rice. Compared with dry direct-seeded rice, the amount of $\mathrm{CH}_{4}$ emission was higher from wet direct-seeded rice, though the variations were statistically insignificant (Fig. 3). On the average for the two rice varieties, the seasonal total $\mathrm{CH}_{4}$ emissions from dry direct-seeded rice, wet directseeded rice, and transplanted rice were $29.7,64.6$, and $165.0 \mathrm{~g} \mathrm{~m}^{-2}$ in 2014 and $35.5,56.8$, and $156.3 \mathrm{~g} \mathrm{~m}^{-2}$ in 
Table 1 Water input for the four rice cultivars under dry direct-seeded rice (DDSR), wet direct-seeded rice (WDSR), and transplanted rice (TR) conditions in 2014 and 2015

\begin{tabular}{|c|c|c|c|c|c|c|c|c|c|c|c|}
\hline \multirow[t]{2}{*}{ Variety } & \multirow{2}{*}{$\begin{array}{l}\text { Establishment } \\
\text { methods }\end{array}$} & \multicolumn{5}{|l|}{2014} & \multicolumn{5}{|l|}{2015} \\
\hline & & $\begin{array}{l}\text { Irrigation } \\
\text { times }\end{array}$ & $\begin{array}{l}\text { Puddling } \\
(\mathrm{mm})\end{array}$ & $\begin{array}{l}\text { Irrigation } \\
(\mathrm{mm})\end{array}$ & $\begin{array}{l}\text { Rainfall } \\
(\mathrm{mm})\end{array}$ & $\begin{array}{l}\text { Total water } \\
\text { input (mm) }\end{array}$ & $\begin{array}{l}\text { Irrigation } \\
\text { times }\end{array}$ & $\begin{array}{l}\text { Puddling } \\
(\mathrm{mm})\end{array}$ & $\begin{array}{l}\text { Irrigation } \\
(\mathrm{mm})\end{array}$ & $\begin{array}{l}\text { Rainfall } \\
(\mathrm{mm})\end{array}$ & $\begin{array}{l}\text { Total water } \\
\text { input (mm) }\end{array}$ \\
\hline \multirow{3}{*}{ HHZ } & DDSR & 7 & 0 & 353 & 742 & 1095 & 8 & 0 & 604 & 537 & 1141 \\
\hline & WDSR & 9 & 63 & 406 & 715 & 1183 & 9 & 63 & 610 & 537 & 1210 \\
\hline & TR & 9 & 124 & 283 & 742 & 1149 & 10 & 216 & 533 & 537 & 1286 \\
\hline \multirow[t]{3}{*}{ LDQ7 } & DDSR & 7 & 0 & 353 & 809 & 1162 & 8 & 0 & 604 & 563 & 1167 \\
\hline & WDSR & 9 & 63 & 406 & 782 & 1250 & 9 & 63 & 610 & 563 & 1236 \\
\hline & $\mathrm{TR}$ & 9 & 124 & 283 & 809 & 1216 & 10 & 216 & 533 & 563 & 1312 \\
\hline \multirow[t]{3}{*}{ YLY6 } & DDSR & 7 & 0 & 353 & 809 & 1162 & 8 & 0 & 604 & 563 & 1167 \\
\hline & WDSR & 9 & 63 & 406 & 782 & 1250 & 9 & 63 & 610 & 563 & 1236 \\
\hline & $\mathrm{TR}$ & 9 & 124 & 283 & 809 & 1216 & 10 & 216 & 533 & 563 & 1312 \\
\hline \multirow[t]{3}{*}{ YLY1 } & DDSR & 7 & 0 & 353 & 809 & 1162 & 8 & 0 & 604 & 563 & 1167 \\
\hline & WDSR & 9 & 63 & 406 & 782 & 1250 & 9 & 63 & 610 & 563 & 1236 \\
\hline & TR & 9 & 124 & 283 & 809 & 1216 & 10 & 216 & 533 & 563 & 1312 \\
\hline
\end{tabular}

Total water input $=$ puddling + irrigation + rainfall

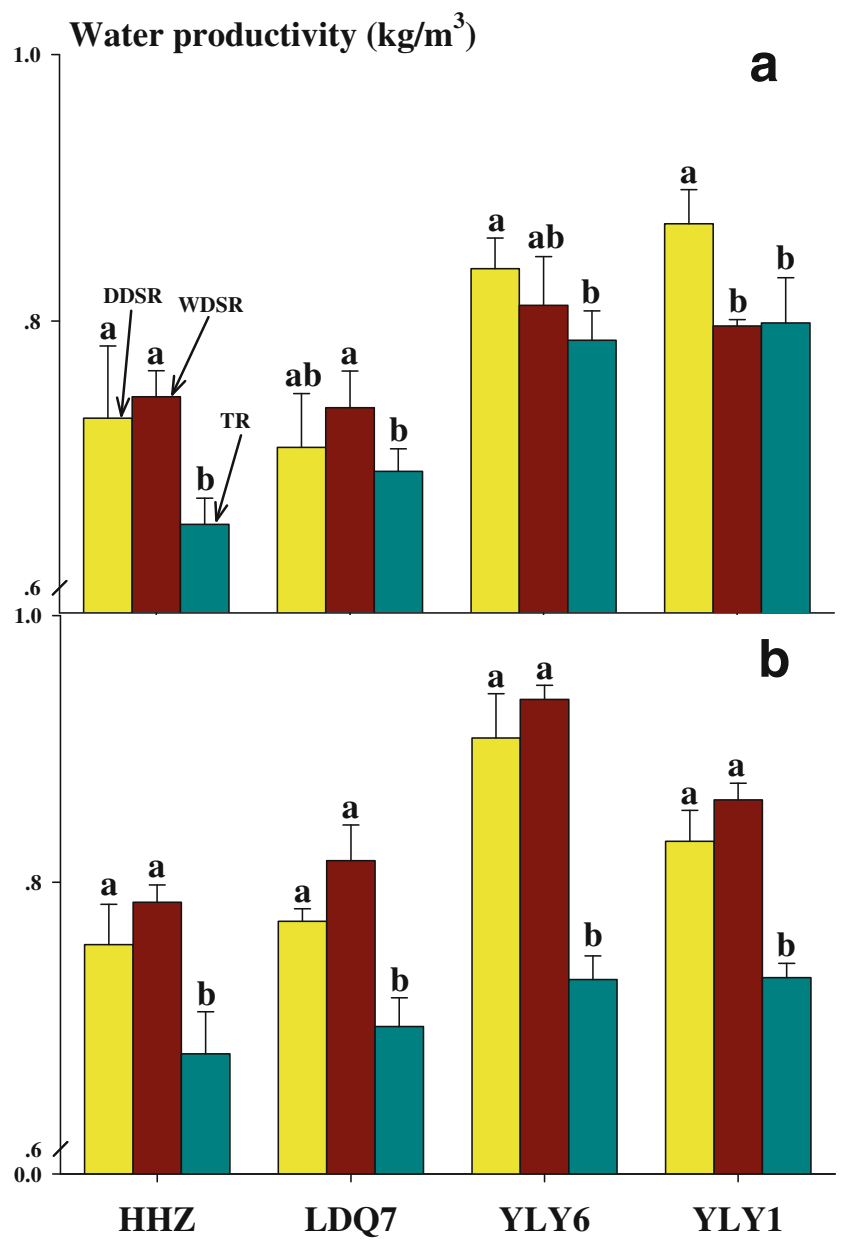

Fig. 2 Water productivity for the four rice cultivars under dry directseeded rice $(D D S R)$, wet direct-seeded rice (WDSR), and transplanted rice $(T R)$ conditions in 2014 (a) and 2015 (b). Huanghuazhan (HHZ), LvdaoQ7 (LDQ7), Yangliangyou6 (YLY6), and Yliangyou1 (YLY1). The different letters above the bars indicate that the difference between the two bars is significant at LSD $(0.05)$
2015, respectively (Fig. 3a). The seasonal total $\mathrm{N}_{2} \mathrm{O}$ emissions were significantly affected by water management. There were long periods of waterlogging in the three establishment methods; thus, less $\mathrm{N}_{2} \mathrm{O}$ emissions were detected. However, significantly higher $\mathrm{N}_{2} \mathrm{O}$ emissions were observed in dry direct-seeded rice than the other two establishment methods in 2014, while there were no significant differences in $\mathrm{N}_{2} \mathrm{O}$ emissions among the three establishment methods in 2015 (Fig. 3b). Global warming potential was calculated from seasonal $\mathrm{CH}_{4}$ and $\mathrm{N}_{2} \mathrm{O}$ emissions; it actually depended mainly on seasonal $\mathrm{CH}_{4}$ emissions among the establishment methods in the present study. Compared with transplanted rice, global warming potential from dry direct-seeded rice or wet directseeded rice was decreased by 76.9 or $58.5 \%$ in 2014 and 75.4 or $62.2 \%$ in 2015, respectively (Fig. 3c).

In our study, the highest grain yield was achieved in wet direct-seeded rice, while there were no significant differences in grain yields between dry direct-seeded rice and transplanted rice (Table 2). The highest grain yield of wet direct-seeded rice among three establishment methods was attributed to its highest panicle number per square meter resulting from higher tillering ability. Gangwar et al. (2009) and Rickman et al. (2001) have documented that with proper management practices, wet direct-seeded rice can obtain an even higher grain yield than transplanted rice. However, serious lodging occurred in the hybrid variety YLiangyoul at the late grain filling stage (7 days to harvest) in wet direct-seeded rice, which resulted in reduced yield gap to transplanted rice (Table 2). This is because a high seeding rate for direct-seeded rice is usually adopted as compensation for poor crop establishment. The high seeding rate in direct-seeded rice leads to high plant density, which provides a favorable micro-environment for crop diseases. High plant density also brings about smaller stem diameters and thinner stem walls. It was documented that the distribution of roots in direct-seeded rice was mostly 

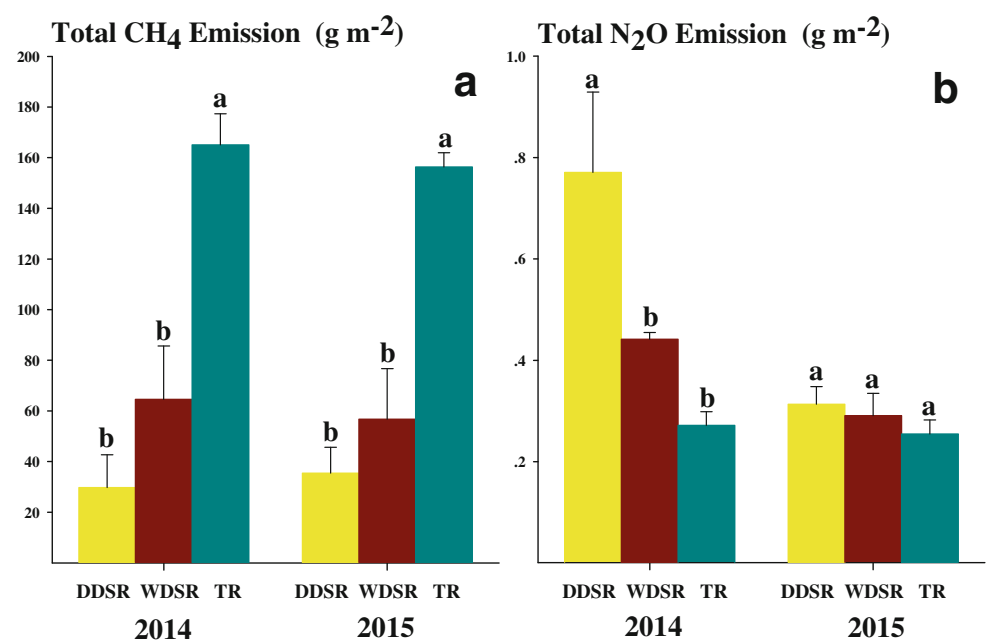

GWP ( $\mathrm{g} \mathrm{CO}_{2}$ equalivent $\left.\mathbf{m}^{-2}\right)$

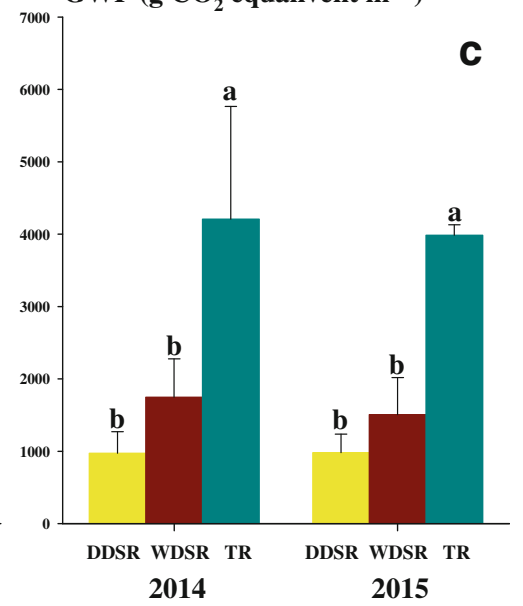

Fig. 3 Total $\mathrm{CH}_{4}$ emissions (a), $\mathrm{N}_{2} \mathrm{O}$ emissions (b), and global warming potential (c) under dry direct-seeded rice $(D D S R)$, wet direct-seeded rice (WDSR), and transplanted rice (TR) conditions in 2014 and 2015. Each

in a shallow soil layer compared to transplanted rice (Kato and Okami 2010). In our study, the measured lodging index was significantly higher in wet direct-seeded rice than in dry direct-seeded rice or transplanted rice, because of the significant higher height of gravitational center, smaller diameters, and thinner stem walls of the third and fourth internodes from the top in wet direct-seeded rice (data not shown). All of these differences indicate that wet direct-seeded rice is more data point is the average of two rice cultivars. GWP global warming potential. The different letters above the bars indicate that the difference between the two bars is significant at LSD (0.05)

susceptible to lodging than the transplanted rice during late grain filling stage. However, a range of approaches have been suggested to mitigate the risk of lodging, such as reducing the plant density by use of appropriate seeding rate, decreasing $\mathrm{N}$ application at tillering stage, and controlling diseases and pests. In addition, cultivars with the characters of intermediate plant heights, large stem diameters, thick stem walls, and high lignin contents should be bred for wet direct-seeded rice to
Table 2 Grain yield and yield components of the four rice cultivars under dry direct-seeded rice (DDSR), wet direct-seeded rice (WDSR), and transplanted rice (TR) conditions in 2014 and 2015

\begin{tabular}{|c|c|c|c|c|c|c|c|}
\hline Variety & $\begin{array}{l}\text { Establishment } \\
\text { methods }\end{array}$ & $\begin{array}{l}\text { Grain } \\
\text { yield } \\
\left(\mathrm{t} \mathrm{ha}^{-1}\right)\end{array}$ & $\begin{array}{l}\text { Spikelets } \\
\left(\mathrm{m}^{-2} \times 10^{3}\right)\end{array}$ & $\begin{array}{l}\text { Panicles } \\
\left(\mathrm{m}^{-2}\right)\end{array}$ & $\begin{array}{l}\text { Spikelets } \\
\text { per panicle }\end{array}$ & $\begin{array}{l}\text { Grain } \\
\text { filling } \\
(\%)\end{array}$ & $\begin{array}{l}1000- \\
\text { GW (g) }\end{array}$ \\
\hline \multicolumn{8}{|l|}{2014} \\
\hline & DDSR & $7.96 \mathrm{~b}$ & $40.22 \mathrm{a}$ & $353 \mathrm{~b}$ & $113.9 \mathrm{~b}$ & $84.7 \mathrm{~b}$ & $20.9 \mathrm{a}$ \\
\hline \multirow[t]{3}{*}{ HHZ } & WDSR & $8.80 \mathrm{a}$ & $42.07 \mathrm{a}$ & $405 \mathrm{a}$ & $104.2 \mathrm{c}$ & 86.9 a & $20.6 \mathrm{a}$ \\
\hline & TR & $7.55 \mathrm{~b}$ & $35.97 \mathrm{~b}$ & $287 \mathrm{c}$ & $125.6 \mathrm{a}$ & $83.8 \mathrm{~b}$ & $20.6 \mathrm{a}$ \\
\hline & DDSR & $8.19 \mathrm{~b}$ & $42.12 \mathrm{~b}$ & $236 \mathrm{~b}$ & $178.2 \mathrm{a}$ & $88.4 \mathrm{a}$ & $23.7 \mathrm{a}$ \\
\hline \multirow[t]{3}{*}{ LDQ7 } & WDSR & $9.00 \mathrm{a}$ & $50.73 \mathrm{a}$ & $274 a$ & $185.6 \mathrm{a}$ & $84.9 \mathrm{ab}$ & $22.6 \mathrm{~b}$ \\
\hline & TR & $8.36 \mathrm{ab}$ & $49.57 \mathrm{a}$ & $261 \mathrm{a}$ & $190.3 \mathrm{a}$ & $81.4 \mathrm{~b}$ & $21.9 \mathrm{~b}$ \\
\hline & DDSR & $9.60 \mathrm{ab}$ & $41.05 \mathrm{~b}$ & $273 \mathrm{~b}$ & $150.2 \mathrm{~b}$ & $89.7 \mathrm{a}$ & $28.6 \mathrm{a}$ \\
\hline \multirow[t]{3}{*}{ YLY6 } & WDSR & $10.15 \mathrm{a}$ & $48.55 \mathrm{a}$ & $326 \mathrm{a}$ & $149.1 \mathrm{~b}$ & $86.2 \mathrm{a}$ & $27.7 \mathrm{~b}$ \\
\hline & $\mathrm{TR}$ & $9.55 \mathrm{~b}$ & $46.51 \mathrm{ab}$ & $255 \mathrm{~b}$ & $183.1 \mathrm{a}$ & $87.0 \mathrm{a}$ & $26.9 \mathrm{c}$ \\
\hline & DDSR & $9.90 \mathrm{a}$ & $47.45 \mathrm{a}$ & $315 a b$ & $150.5 \mathrm{a}$ & $91.9 \mathrm{a}$ & $25.0 \mathrm{a}$ \\
\hline \multirow[t]{2}{*}{ YLY1 } & WDSR & $9.95 \mathrm{a}$ & $49.52 \mathrm{a}$ & $335 \mathrm{a}$ & $148.4 \mathrm{a}$ & $88.3 \mathrm{~b}$ & $23.9 \mathrm{~b}$ \\
\hline & $\mathrm{TR}$ & $9.71 \mathrm{a}$ & $44.69 \mathrm{a}$ & $286 \mathrm{~b}$ & $156.6 \mathrm{a}$ & $89.8 \mathrm{ab}$ & $24.2 \mathrm{~b}$ \\
\hline \multicolumn{8}{|l|}{2015} \\
\hline \multirow{4}{*}{ HHZ } & DDSR & $8.59 \mathrm{~b}$ & $50.48 \mathrm{a}$ & $390 \mathrm{~b}$ & $129.4 \mathrm{a}$ & $77.5 \mathrm{~b}$ & $20.1 \mathrm{~b}$ \\
\hline & WDSR & $9.50 \mathrm{a}$ & $53.63 \mathrm{a}$ & $485 \mathrm{a}$ & $110.6 \mathrm{~b}$ & $81.6 \mathrm{a}$ & $20.6 \mathrm{a}$ \\
\hline & TR & $8.63 \mathrm{~b}$ & $41.36 \mathrm{~b}$ & $309 \mathrm{c}$ & $133.9 \mathrm{a}$ & $83.8 \mathrm{~b}$ & $20.8 \mathrm{a}$ \\
\hline & DDSR & $8.99 \mathrm{~b}$ & $40.09 \mathrm{a}$ & $289 \mathrm{~b}$ & $138.8 \mathrm{a}$ & $84.4 \mathrm{a}$ & $24.8 \mathrm{a}$ \\
\hline \multirow[t]{3}{*}{ LDQ7 } & WDSR & $10.09 \mathrm{a}$ & $43.23 \mathrm{a}$ & $355 \mathrm{a}$ & $122.9 \mathrm{a}$ & $86.6 \mathrm{a}$ & $24.0 \mathrm{a}$ \\
\hline & TR & $9.07 \mathrm{~b}$ & $35.07 \mathrm{~b}$ & $260 \mathrm{~b}$ & $135.5 \mathrm{a}$ & $86.4 \mathrm{a}$ & $24.6 \mathrm{a}$ \\
\hline & DDSR & $10.60 \mathrm{~b}$ & $38.30 \mathrm{~b}$ & $291 \mathrm{ab}$ & $132.8 \mathrm{a}$ & $88.5 \mathrm{a}$ & $28.3 \mathrm{a}$ \\
\hline \multirow[t]{3}{*}{ YLY6 } & WDSR & $11.59 \mathrm{a}$ & $42.63 \mathrm{a}$ & $344 \mathrm{a}$ & $124.4 \mathrm{a}$ & $86.4 \mathrm{a}$ & $27.7 \mathrm{a}$ \\
\hline & TR & $9.54 \mathrm{c}$ & $35.29 \mathrm{c}$ & $256 \mathrm{~b}$ & $138.2 \mathrm{a}$ & $87.6 \mathrm{a}$ & $28.1 \mathrm{a}$ \\
\hline & DDSR & $9.69 \mathrm{~b}$ & $39.77 \mathrm{~b}$ & $345 \mathrm{a}$ & $150.2 \mathrm{~b}$ & $83.0 \mathrm{a}$ & $25.8 \mathrm{a}$ \\
\hline \multirow[t]{2}{*}{ YLY1 } & WDSR & $10.65 \mathrm{a}$ & $46.72 \mathrm{a}$ & $397 \mathrm{a}$ & $149.1 \mathrm{~b}$ & $83.8 \mathrm{a}$ & $24.1 \mathrm{~b}$ \\
\hline & TR & $9.55 \mathrm{~b}$ & $35.92 \mathrm{~b}$ & $291 \mathrm{~b}$ & $183.1 \mathrm{a}$ & $86.6 \mathrm{a}$ & $25.9 \mathrm{a}$ \\
\hline
\end{tabular}

There is a column for each cultivar. The means are followed by different letters that represent different significances at a 0.05 probability level according to the least significant difference (LSD) test 
reduce the lodging susceptibility (Mackill et al. 1996). In dry direct-seeded rice, weeds are one of the main limiting factors to its wider diffusion among the farmers. Weeds germinate with rice after land preparation and escape suppression by the water layer. High weed infestation can cause $74 \%$ yield losses under the dry direct-seeded rice system (Ramzan 2003). Thus, it is necessary to take effective and sustainable weed management measures for dry direct-seeded rice.

Due to severe water shortage in Central China, dry directseeded rice can be a water-saving establishment method. In the present study, the total water input for dry direct-seeded rice was lower than that for transplanted rice (Table 1); therefore, the water productivity was significantly higher in dry direct-seeded rice than that in transplanted rice (Fig. 2) due to the comparable grain yield. Consequently, dry directseeded rice is capable of increasing water productivity while also reducing labor consumption. Generally, the amount of water input in wet direct-seeded rice should be less than that of transplanted rice. However, irrigation water input (including puddling and irrigation) in wet direct-seeded rice was $15 \%$ greater than that in transplanted rice in 2014 (Table 1). In our study, the total water consumption including rainfall and irrigation for direct-seeded rice was recorded after direct sowing in the field, while the water consumption for transplanted rice was recorded only after seedling transplantation, so the water input during nursery period was not recorded for transplanted rice. In our study, the water saving in direct-seeded rice was not so evident because the plots were kept under flooded conditions soon after crop establishment. Some water management practices could be adopted to further save the water input and increase water productivity in directseeded rice, such as rainfed (Zhao et al. 2007), alternate wet and dry (Bouman and Tuong 2001), regulated deficit irrigation (Chai et al. 2016). Yoshida (1981) reported that $1240 \mathrm{~mm}$ was an average water requirement to produce a reasonably good crop of rice. Although Bouman et al. (2005) documented that the total water input of rainfed rice in tropical regions could be reduced to $790 \mathrm{~mm}$, rainfed rice has shown a severe yield penalty. At our experimental site, the average rainfall during the growth duration was $670 \mathrm{~mm}(783 \mathrm{~mm}$ in 2014 and $557 \mathrm{~mm}$ in 2015), which was around half of the average water requirement for good rice growth. Furthermore, wellestablished irrigation infrastructure and enough freshwater resources in Central China ensured adequate irrigation. Thus, in our present experiments, dry direct-seeded rice was grown under irrigated-flood conditions during the growth duration except for early vegetative stage.

It has been well documented that the $\mathrm{CH}_{4}$ and $\mathrm{N}_{2} \mathrm{O}$ emissions from rice paddies over the past decades (Ko et al. 2002; Qin et al. 2010); however, few studies have focused on the difference between different direct-seeded rice systems and transplanted rice in $\mathrm{CH}_{4}$ and $\mathrm{N}_{2} \mathrm{O}$ fluxes under well-watered soil conditions. Our study indicates that seasonal total $\mathrm{CH}_{4}$ emission from transplanted rice was significantly higher than that from dry direct-seeded rice and wet direct-seeded rice, which was consistent with previous studies (Harada et al. 2007; Ko et al. 2002). In 2014, water consumption with wet direct-seeded rice is greater than that with transplanted rice (Table 1); however, total $\mathrm{CH}_{4}$ emission with wet directseeded rice was significantly lower than that with transplanted rice (Fig. 3). The opposite trends between water consumption and total $\mathrm{CH}_{4}$ emission might be explained by two aspects. Firstly, the total water consumption with wet direct-seeded rice was not necessarily greater than transplanted rice, because we did not record the water input during nursery period for transplanted rice. Secondly, the root system of direct-seeded rice differs from that of transplanted rice. It might be possible that the roots of wet direct-seeded rice were shallower than that of transplanted rice. With more roots present at the $0-10$ $\mathrm{cm}$ depth, there could be more $\mathrm{CH}_{4}$ oxidized to $\mathrm{CO}_{2}$, thus reducing the $\mathrm{CH}_{4}$ emission (Corton et al. 2000; Watanabe et al. 1997).

In summary, despite the relatively higher $\mathrm{N}_{2} \mathrm{O}$ emissions in dry direct-seeded rice and wet direct-seeded rice, global warming potential of direct-seeded rice is lower than that of transplanted rice because of substantially low $\mathrm{CH}_{4}$ emissions in direct-seeded rice. Furthermore, considering the grave threats from global warming, more appropriate greenhouse gas emission strategies must involve ecologically intensive food crop management practices that enhance resource use efficiency and maintain high yields (Cassman 1999). Seeking a new type of fertilizer could be one solution. Rose et al. (2014) reported that the biofertilizer containing plant growth promoting microorganisms could replace between 23 and $52 \%$ of nitrogen $(\mathrm{N})$ fertilizer without loss of yield. Ali et al. (2014) also reported that Anabaena azollae in combination with urea and silicate fertilization decreased the total seasonal $\mathrm{CH}_{4}$ flux by $12 \%$ and increased rice grain yield by $10.6 \%$. Furthermore, a carrier that consisted of a mixture of rice straw and rice husk ash in a 4:1 ratio with Rhodopseudomonas palustris could reduce the $\mathrm{CH}_{4}$ and $\mathrm{CO}_{2}$ emissions simultaneously (Kantha et al. 2015).

\section{Conclusions}

Direct-seeded rice is a feasible and sustainable alternative to transplanted rice in Central China based on comparable or even higher yield performances and greater water use efficiency. Wet direct-seeded rice is a competitive establishment method in Central China due to its higher grain yield, water productivity, and lower global warming potential than transplanted rice. Dry direct-seeded rice may be suitable for regions where water levels are low for soil puddling during land preparation, especially when considering comparable grain yield, less irrigation, and lower global warming potential 
in comparison with transplanted rice. However, we should also comprehensively consider the threats from weeds, the lodging problem, and pests and disease when we advocate direct-seeded rice.

Acknowledgments This work was supported by the National Natural Science Foundation of China (Project No. 31371571) and the Fundamental Research Funds for the Central Universities (Project No. 2013PY109).

\section{References}

Ali M, Sattar M, Islam M, Inubushi K (2014) Integrated effects of organic, inorganic and biological amendments on methane emission, soil quality and rice productivity in irrigated paddy ecosystem of Bangladesh: field study of two consecutive rice growing seasons. Plant Soil 378:239-252. doi:10.1007/ s11104-014-2023-y

Barker R, Dae D, Tuong T, Bhuiyan S, Guerra L (1998) The outlook for water resources in the year 2020: challenges for rice research on water management in rice production. IRRI, Los Baños, p 2. doi: 10.1065/espr2004.12.227

Bouman B (2009) How much water does rice use? Management 69:115133

Bouman B, Tuong T (2001) Field water management to save water and increase its productivity in irrigated lowland rice. Agr Water Manage 49:11-30. doi:10.1016/S0378-3774(00)00128-1

Bouman B, Peng S, Castaneda AR, Visperas RM (2005) Yield and water use of irrigated tropical aerobic rice systems. Agr Water Manage 74: 87-105. doi:10.1016/j.agwat.2004.11.007

Carriger S, Vallée D (2007) More crop per drop. Rice Today 6:10-13. doi: $10.1038 / 452273 a$

Cassman KG (1999) Ecological intensification of cereal production systems: yield potential, soil quality, and precision agriculture. Proc Natl Acad Sci 96:5952-5959. doi:10.1073/pnas.96.11.5952

Chai Q, Gan Y, Zhao C, Xu HL, Waskom RM, Niu Y, Siddique KH (2016) Regulated deficit irrigation for crop production under drought stress. A review. Agron Sustain Dev 36:1-21. doi:10. 1007/s13593-015-0338-6

Chen C, Cao G, Zhang M (2015) Development trend forecast and equipment requirements of the rice transplanting mechanization. J Yunnan Agri Univ 30:289-293. doi:10.16211/j.isssn. 1004-390X(n). 2015.02.020, In Chinese with English abstract

Corton T, Bajita J, Grospe F, Pamplona R, Asis J, Wassmann R, Buendia L (2000) Methane emission from irrigated and intensively managed rice fields in Central Luzon (Philippines). In: Methane emissions from major rice ecosystems in Asia. Springer, Netherlands, pp 37-53. doi:10.1007/978-94-0100898-3 4

Farooq M, Siddique KH, Rehman H, Aziz T, Lee D-J, Wahid A (2011) Rice direct seeding: experiences, challenges and opportunities. Soil Till Res 111:87-98. doi:10.1016/j.still.2010.10.008

Gangwar K, Chaudhary V, Gangwar B, Pandey D (2009) Effect of crop establishment and tillage practices in rice (Oryza sativa L)-based cropping systems. Indian J Agr Sci 79:334-339

Harada H, Kobayashi H, Shindo H (2007) Reduction in greenhouse gas emissions by no-tilling rice cultivation in Hachirogata polder, northern Japan: life-cycle inventory analysis. Soil Sci Plant Nutr 53:668-677. doi:10.1111/j.17470765.2007.00174.x
Kantha T, Kantachote D, Klongdee N (2015) Potential of biofertilizers from selected Rhodopseudomonas palustris strains to assist rice (Oryza sativa L. subsp. indica) growth under salt stress and to reduce greenhouse gas emissions. Ann Microbiol 65:2109-2118. doi:10. 1007/s13213-015-1049-6

Kato Y, Okami M (2010) Root growth dynamics and stomatal behaviour of rice (Oryza sativa L.) grown under aerobic and flooded conditions. Field Crop Res 117:9-17. doi:10.1016/j. fcr.2009.12.003

Ko J, Lee J, Kim M, Gang H, Kang W, Lee D, Sin Y, Kim K, Lee K (2002) Effects of cultural practices on methane emission in tillage and no-tillage practice from rice paddy fields. Kor J Soil Sci Fert 35: 216-222

Kumar V, Ladha JK (2011) Direct seeding of rice: recent developments and future research needs. Adv Agron 111:297-413. doi:10.1016/ B978-0-12-387689-8.00001-1

Lashof DA, Ahuja DR (1990) Relative contributions of greenhouse gas emissions to global warming. Nature 344:529-531. doi:10.1038/ 344529a0

Mackill DJ, Coffman WR, Garrity DP (1996) Rainfed lowland rice improvement. IRRI, Los Baños, pp 53-56

Mitchell J, Fukai S, Basnayake J (2004) Grain yield of direct seeded and transplanted rice in rainfed lowlands of South East Asia. In: Proceedings of the 4th International Crop Science Congress Brisbane, Australia. pp 81-90.

Pathak H, Bhatia A, Prasad S, Singh S, Kumar S, Jain M, Kumar U (2002) Emission of nitrous oxide from rice-wheat systems of IndoGangetic plains of India. Environ Monit Assess 77:163-178. doi:10. 1023/A:1015823919405

Peng S, Tang Q, Zou Y (2009) Current status and challenges of rice production in China. Plant Prod Sci 12:3-8. doi:10.1626/pps.12.3

Qin Y, Liu S, Guo Y, Liu Q, Zou J (2010) Methane and nitrous oxide emissions from organic and conventional rice cropping systems in Southeast China. Biol Fert Soils 46:825-834. doi:10.1007/s00374010-0493-5

Ramzan M (2003) Evaluation of various planting methods in ricewheat cropping systems, Punjab, Pakistan. Rice Crop Rep 2004:4-5

Rose MT, Phuong TL, Nhan DK, Cong PT, Hien NT, Kennedy IR (2014) $\mathrm{Up}$ to $52 \% \mathrm{~N}$ fertilizer replaced by biofertilizer in lowland rice via farmer participatory research. Agron Sustain Dev 34:857-868. doi: 10.1007/s13593-014-0210-0

Rickman J, Pyseth M, Bunna S, Sinath P, Fukai S, Basnayake J (2001) Direct seeding of rice in Cambodia. In: Increased lowland rice production in the Mekong Region: proceedings of an International Workshop held in Vientiane, Laos, 30 October-2 November 2000. Australian Centre for International Agricultural Research (ACIAR), Canberra, pp 60-65

Shang Q, Yang X, Gao C, Wu P, Liu J, Xu Y, Shen Q, Zou J, Guo S (2011) Net annual global warming potential and greenhouse gas intensity in Chinese double rice-cropping systems: a 3-year field measurement in long-term fertilizer experiments. Global Change Biol 17:2196-2210. doi:10.1111/j. 1365-2486.2010.02374.x

Smith P, Martino D, Cai Z, Gwary D, Janzen H, Kumar P, McCarl B, Ogle S, O'Mara F, Rice C (2007) Climate change 2007: mitigation. Contribution of working group III to the fourth assessment report of the Intergovernmental Panel on Climate Change. Climate change 2007: mitigation Contribution of Working Group III to the Fourth Assessment Report of the Intergovernmental Panel on Climate Change

Wang L, Wu C, Gao L, Tu A, Jin C (2006) The paddy planting status and the research of developing paddy mechanical direct seeding in China. J Agr Mech Res 3:28-30 (In Chinese with English abstract) 
Wassmann R, Neue H, Ladha J, Aulakh M (2004) Mitigating greenhouse gas emissions from rice-wheat cropping systems in Asia. In: Tropical Agriculture in Transition-Opportunities for Mitigating Greenhouse Gas Emissions? Springer, pp 65-90. doi:10.1007/97894-017-3604-6 4

Watanabe I, Hashimoto T, Shimoyama A (1997) Methane-oxidizing activities and methanotrophic populations associated with wetland rice plants. Biol Fert Soils 24:261-265. doi:10.1007/ s003740050241

Yoshida S (1981) Fundamentals of rice crop science. Los Baños, Philippines

Zhao C, Jiang H, Ren C, Yin Y, Li Y (2007) Studies on key techniques of sowing rice directly on dry land for high yield and high efficiency. $\mathrm{J}$ Jilin Agri Sci 32:9-11 (In Chinese with English abstract) 